\title{
The Dopamine Stabilizer (-)-OSU6162 Occupies a Subpopulation of Striatal Dopamine D2/D3 Receptors: An [ ' C]Raclopride PET Study in Healthy Human Subjects
}

\author{
Nelleke Tolboom*,', Henk W Berendse², Josee E Leysen', Maqsood Yaqub', Bart NM van Berckel', \\ Robert C Schuit', Mirthe M Ponsen², Esther Bakker', Nikie J Hoetjes', Albert D Windhorst', \\ Maria L Carlsson ${ }^{3}$, Adriaan A Lammertsma' and Arvid Carlsson ${ }^{3}$ \\ 'Department of Radiology and Nuclear Medicine, VU University Medical Center, Amsterdam, The Netherlands; ${ }^{2}$ Department of Neurology, \\ VU University Medical Center, Amsterdam, The Netherlands; ${ }^{3}$ Institute of Neuroscience and Physiology, The Sahlgrenska Academy at the \\ University of Gothenburg, Gothenburg, Sweden
}

( - )-OSU6I62 is a dopamine stabilizer that can counteract both hyperdopaminergic and hypodopaminergic states. In this study, D2/D3 receptor occupancy of (-)-OSU6I62 in the human brain was investigated using positron emission tomography (PET). Twelve male healthy volunteers underwent $\left[{ }^{1}\right.$ C C]raclopride PET scanning before and I h after a single oral dose of ( - )-OSU6I62 (I5-90 mg). Blood samples for determination of ( - )-OSU6I62 and prolactin plasma levels were collected at $T_{\max }$. Parametric images of [ I $C$ ]raclopride binding potential relative to nondisplaceable tissue (cerebellar grey matter) uptake $\left(B P_{N D}\right)$ at baseline and after (-)-OSU6I62 administration were generated using the simplified reference tissue model. MRI-based regions of interest were defined for the striatum,

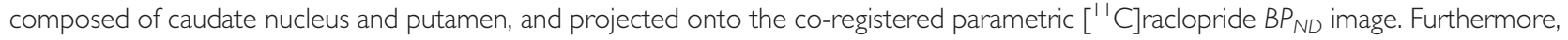
three striatal subregions, ie, anterior dorsal caudate, anterior dorsal putamen, and ventral striatum, were defined manually and additionally analyzed. Plasma concentrations of (-)-OSU6162, ranging from 0.01 to $0.9 \mu \mathrm{M}$, showed a linear relationship with prolactin levels, reflecting blockade of pituitary D2 receptors. A concentration-dependent increase in striatal D2/D3 receptor occupancy was observed, reaching a value of about $20 \%$ at an ( - )-OSU6 162 plasma level of $0.2 \mu \mathrm{M}$, and which for higher concentrations leveled off to a maximal occupancy of about $40 \%$. Findings were similar in the striatal subregions. The present data corroborate the notion that (- )-OSU6I62 binds preferentially to a subpopulation of D2/D3 receptors, possibly predominantly extrasynaptic, and this may form the basis for the dopamine-stabilizing properties of ( - )-OSU6I62.

Neuropsychopharmacology (20I5) 40, 472-479; doi:I0.1038/npp.20I4.195; published online 24 September 20I4

\section{INTRODUCTION}

( - )-OSU6162 ((3S)-3-[3-(methylsulfonyl)phenyl]-1-propylpiperidine hydrochloride) has been classified as a 'dopamine stabilizer' because of its affinity for dopaminergic $\mathrm{D} 2 / \mathrm{D} 3$ receptors in conjunction with its ability to inhibit or stimulate dopamine-related behavior, depending on the baseline motor activity level. At high baseline level (-)OSU6162 inhibits and at low baseline level it stimulates behavior (Rung et al, 2008). In vitro, the compound shows moderate (micromolar) affinity for D2/D3 receptors with very low intrinsic activity (Burstein et al, 2011). In vivo, however, it appears to be an antagonist devoid of intrinsic activity over a wide range of doses (Carlsson et al, 2011;

*Correspondence: Dr N Tolboom, Department of Radiology and Nuclear Medicine, VU University Medical Center, PO Box 7057, Amsterdam 1007 MB, The Netherlands, Tel: +31 20 4444214, Fax: +31 20 4442831, E-mail: n.tolboom@vumc.nl

Received 23 December 2013; revised 14 June 2014; accepted 16 June 20।4; accepted article preview online 5 August 2014
Rung et al, 2011). Evidence in humans of a dopamine D2 antagonistic action of (-)-OSU6162, at the level of the pituitary, was demonstrated indirectly by a dose-dependent elevation in serum prolactin (Rodriguez et al, 2004). Although (-)-OSU6162 also demonstrates affinity for serotonergic 5-HT1 and 5-HT2 receptors, in both cases acting as a partial agonist (Burstein et al, 2011; Carlsson et al, 2011), and for sigma sites (Sahlholm et al, 2013), especially its effects on the dopamine system have been well characterized. For example, the ability of (-)-OSU6162 to counteract amphetamine-induced hyperactivity is lost in dopamine D2 knockout mice (Svensson et al, 2009). Activation of habituated rats appears to depend largely on dopaminergic stimulation mediated via preferential antagonism on dopaminergic autoreceptors, possibly in conjunction with an allosteric mechanism (Lahti et al, 2007; Rung et al, 2008).

Although (-)-OSU6162 receptor occupancy data are available for rats (Natesan et al, 2006) and Rhesus monkeys (Ekesbo et al, 1999), no human studies have been reported yet. There is an increasing need for human imaging data in view of 
the ongoing accumulation of both preclinical and clinical observations showing the substance's promise for treating a variety of neuropsychiatric disorders such as Huntington's disease, schizophrenia, and mental fatigue following stroke or head trauma (Tedroff et al, 1999; Johansson et al, 2012; Kloberg et al, 2014; Carlsson A, unpublished observation).

The aim of the present study was to investigate D2/D3 receptor occupancy of $(-)$-OSU6162 in the human brain in order to better understand its dopamine-stabilizing properties.

\section{MATERIALS AND METHODS}

\section{Subject Selection Procedure}

Male subjects, in the age range of 50-60 years, were recruited through newspaper advertisements. All subjects received a screening that included medical history, physical, and neurological examinations, screening laboratory tests, toxicology screening of urine (opiates, cocaine, amphetamines, cannabis, methadone, benzodiazepines, and barbiturates), and brain magnetic resonance imaging (MRI). Exclusion criteria were any history of major psychiatric or neurological illness, use of any centrally active medication, including anti-psychotic or anti-depressant medication, use of any investigational medication within 30 days prior to the start of this study, (history of) alcohol and/or drug abuse (DSM-IV criteria), any sign of cardiovascular disease, and claustrophobia. All subjects were instructed to refrain from alcohol consumption during $24 \mathrm{~h}$ prior to testing. Two volunteers were habitual smokers. Subjects were not allowed to smoke or drink grapefruit juice on the day of the positron emission tomography (PET) study.

Prior to inclusion, written informed consent was obtained from all subjects after a complete written and verbal description of the study.

\section{( - )-OSU6162 Clinical Samples, Safety, and Pharmacokinetic Data}

(-)-OSU6162 was prepared under GMP conditions at 'Syntagon' (Södertälje, Sweden) and 'Galenica AB' (Malmö, Sweden) as described previously (Sonesson et al, 1994). Safety data for (-)-OSU6162 are available from a phase I study using single oral doses of up to $200 \mathrm{mg}$. Potential adverse effects of $(-)$-OSU6162 administration are on the central nervous system and the cardiovascular system. Single oral doses of (-)-OSU6162 up to $150 \mathrm{mg}$ appeared safe and well tolerated. (-)-OSU6162 plasma levels were reported to reach peak values $\left(T_{\max }\right)$ at $1-1.5 \mathrm{~h}$ (Rodriguez et al, 2004).

\section{Study Design}

Twelve male healthy volunteers underwent $\left[{ }^{11} \mathrm{C}\right]$ raclopride PET scans before and $1 \mathrm{~h}$ after a single oral dose of $(-)$ OSU6162.

Subjects received the following single oral doses of $(-)$ OSU6162: $15 \mathrm{mg}(n=3), 30 \mathrm{mg}(n=2), 45 \mathrm{mg}(n=2), 60 \mathrm{mg}$ $(n=1)$, and $90 \mathrm{mg}(n=3)$. A starting dose of $15 \mathrm{mg}$ was chosen based on data from proof-of-concept clinical studies (Johansson et al, 2012). Subsequent doses were chosen based on the outcomes of the previous PET scans in the current study. The maximum dose was set to a clinically safe and relevant dose of $90 \mathrm{mg}$, well below the previously observed maximally tolerated dose of $150 \mathrm{mg}$ (Rodriguez et al, 2004). The study had been approved by the Medical Ethics Review Committee of the VU University Medical Center Amsterdam.

\section{$\left[{ }^{11} \mathrm{C}\right]$ Raclopride Clinical Samples}

$\left[{ }^{11} \mathrm{C}\right]$ raclopride was synthesized according to a slightly modified procedure reported previously (Ehrin et al, 1987). It was obtained with a radiochemical purity $>98 \%$, a specific activity at the time of injection of $66 \pm 26 \mathrm{GBq} / \mu \mathrm{M}$, and it was manufactured under GMP license at the GMP facility of the department of Radiology and Nuclear Medicine.

\section{Positron Emission Tomography}

PET scans were performed using an ECAT EXACT HR + scanner (Brix et al, 1997) (Siemens/CTI, Knoxville, USA), equipped with a neuro-insert to reduce the contribution of outside field of view (FOV) activity. This scanner enables the acquisition of 63 transaxial planes over a $15.5 \mathrm{~cm}$ axial FOV, thus allowing the whole brain to be imaged in a single bed position. All subjects received a venous cannula for intravenous infusion of $\left[{ }^{11} \mathrm{C}\right]$ raclopride, administered using an infusion pump (Med-Rad, Beek, the Netherlands). Patient motion was restricted by the use of a head holder, and throughout the scanning procedure, the position of the head was monitored using laser beams.

First, a 10 -min transmission scan was performed in $2 \mathrm{D}$ acquisition mode using three retractable rotating line sources. This scan was used to correct the subsequent emission scan for photon attenuation. Next, a 60-min dynamic emission scan in 3D acquisition mode was acquired, starting at the time of $\left[{ }^{11} \mathrm{C}\right]$ raclopride infusion $(369 \pm 14 \mathrm{MBq}$ at a rate of $0.8 \mathrm{ml} / \mathrm{s}$, followed by a flush of $42 \mathrm{ml}$ saline at a rate of $2.0 \mathrm{ml} / \mathrm{s}$ ). Each dynamic emission scan consisted of 21 frames with progressive increase in frame length $(6 \times 5$, $3 \times 10,4 \times 60,2 \times 150,2 \times 300,4 \times 600$ s). Four hours later, an identical scanning sequence was performed $1 \mathrm{~h}$ (ie, at $\left.T_{\max }\right)$ after oral administration of ( - )-OSU6162. The total injected amount of $\left[{ }^{11} \mathrm{C}\right]$ raclopride, averages being $2.31 \pm 0.78 \mu \mathrm{g}$ and $2.16 \pm 0.66 \mu \mathrm{g}$, respectively, did not differ significantly between PET scans at baseline and after pretreatment with $(-)$-OSU6162, $(p=0.70)$.

Blood samples for determination of plasma levels of $(-)$ OSU6162 and prolactin were collected just before the start of the second $\left[{ }^{11} \mathrm{C}\right]$ raclopride scan. Venous whole blood $(10 \mathrm{ml})$ was collected into Vacutainer tubes containing heparin. Specimens were centrifuged for $10 \mathrm{~min}$ at $4{ }^{\circ} \mathrm{C}$, after which the plasma layer was transferred to plastic vials and stored at $-80^{\circ} \mathrm{C}$.

\section{Magnetic Resonance Imaging}

All subjects underwent a structural MRI scan using a 1.5-T Sonata scanner (Siemens Medical Solutions, Erlangen, Germany). The scan protocol included a sagittal T1-weighted 3D MPRAGE (magnetization prepared rapid acquisition gradient echo; slice thickness $1.0 \mathrm{~mm}, 176$ slices; matrix size 
$256 \times 256$; voxel size $1 \times 1 \times 1 \mathrm{~mm}$; echo time $3.97 \mathrm{~ms}$; repetition time $2700 \mathrm{~ms}$; inversion time $950 \mathrm{~ms}$; flip angle $8^{\circ}$ ).

\section{Image and Data Analysis}

All PET sinograms were corrected for dead time, tissue attenuation using the transmission scan, decay, scatter, and randoms and reconstructed using a standard filtered back projection algorithm with a Hanning filter at a cut-off of 0.5 times the Nyquist frequency. A zoom factor of two and a matrix size of $256 \times 256 \times 63$ were used, resulting in a voxel size of $1.2 \times 1.2 \times 2.4 \mathrm{~mm}^{3}$ and a spatial resolution of approximately $7 \mathrm{~mm}$ full-width at half-maximum at the center of the FOV.

Parametric images of $\left[{ }^{11} \mathrm{C}\right]$ raclopride-binding potential relative to non-displaceable uptake $\left(B P_{N D}\right)$ (Innis et al, 2007) were generated using a basis function implementation of the 'two-step' simplified reference tissue model with cerebellar grey matter as reference tissue (Wu and Carson, 2002).

MRI images were aligned to corresponding co-registered PET images using a mutual information algorithm (Maes et al, 1997).

Segmentation of MRI images and region of interest (ROI) analysis of PET data were performed using PVE lab, a software program that uses a probability map of 35 delineated (grey matter) ROIs (Svarer et al, 2005), including caudate nucleus, putamen, and cerebellum. Caudate nucleus and putamen were combined to create a striatal ROI. For an additional subregion analysis, anterior dorsal caudate, anterior dorsal putamen, and ventral striatum were defined manually according to the existing guidelines (Martinez et al, 2003; Mawlawi et al, 2001).

ROIs were projected onto parametric $\left[{ }^{11} \mathrm{C}\right]$ raclopride $B P_{N D}$ images at baseline and after treatment with $(-)$ OSU6162. D2/D3 receptor occupancy Occ (\%) was calculated according to:

$$
\text { Occ }=100 \times\left(1-B P_{N D}^{O S U} / B P_{N D}^{B A S E L I N E}\right)
$$

where $B P_{N D}^{B A S E L I N E}$ and $B P_{N D}^{O S U}$ represent $B P_{N D}$ before and after ( - )-OSU6162 administration, respectively. For each ROI, Occ was plotted as a function of $(-)$-OSU6162 plasma levels and fitted to the following binding equation:

$$
\operatorname{Occ}(\%)=\frac{O c c_{\max } * C_{p}}{\left(C_{p}+E C 50\right)}
$$

where $O c c_{\max }$ and $C_{p}$ represent maximum level of occupancy and plasma level of ( - )-OSU6162, respectively. $E C_{50}$ is defined as the required plasma level of $(-)$-OSU6162 to reach $50 \%$ of the maximum occupancy.

Data are presented as mean $\pm \mathrm{SD}$, unless otherwise stated.

\section{LC-MS/MS Determination of ( - )-OSU6162 Plasma Levels}

A $0.25-\mathrm{ml}$ sample of plasma was deproteinized with $0.25 \mathrm{ml}$ of an $11 \%$ aqueous trichloroacetic acid solution. After $5 \mathrm{~min}$ of ultracentrifugation $(20000 \mathrm{~g})$, the supernatant was transferred to a $2.0-\mathrm{ml}$ amber screw cap vial with a $200-\mu 1$ insert. Plasma concentrations of ( - -)-OSU6162 were quantitatively determined by LC-MS/MS using an optimized stable isotope dilution method (Yamazaki et al, 2009). The injection volume was $2 \mu \mathrm{l}$, and $\left[{ }^{2} \mathrm{H}_{7}\right](-)$-OSU6162 (Syntagon, Södertälje, Sweden) was used as an internal standard. Separation of analytes was performed using a Jasco $\mathrm{X}$-Liquid Chromatography (LC) system with a Kinetex $100 \times 2.1 \mathrm{~mm}^{2}, 1.7 \mu \mathrm{m}$ column (Phenomenex, Torrance, CA, USA) as stationary phase. A gradient mobile phase of acetonitril and $0.1 \%$ ammonium acetate $\mathrm{pH} 3.95$ was used. Mass spectrometry (MS) analysis was performed using a Qtrap5500 (ABSciex, Framingham, MA, USA) with electrospray ionization. Multi-reaction monitoring with transitions $\mathrm{m} / \mathrm{z}$ 282.2-169.1 for (-)-OSU6162 and 289.2-169.2 for $\left[{ }^{2} \mathrm{H}_{7}\right](-)$-OSU6162, respectively, was used. The retention time of (-)-OSU6162 was $3.02 \mathrm{~min}$, and the calibration curve was linear from 0.0029 to $5.0 \mu \mathrm{M}\left(r^{2}=1.00\right)$. The limit of quantification was $5 \mathrm{nM}$, the intra-assay variation was $<5 \%$, and the inter-assay variation $<6 \%$. The metabolic pathways of OSU6162 have been mapped, and no pharmacologically active metabolites have been identified (Wienkers and Wynalda, 2002).

\section{Measurement of Plasma Prolactin Levels}

Prolactin was measured using an immunometric assay (Centaur, Siemens Diagnostics, Deerfield, IL, USA). The lower limit of quantification was $0.05 \mathrm{U} / \mathrm{l}(=2.36 \mathrm{ng} / \mathrm{ml})$, the intra-assay variation was $<5 \%$, and the inter-assay variation $<6 \%$ for the whole concentration range.

\section{RESULTS}

Two subjects were excluded from the study, one due to radiosynthesis failure and the other due to an abnormality on MRI. In total, data were obtained for 10 volunteers (age $51-60$ years, body mass index $21-34 \mathrm{~kg} / \mathrm{m}^{2}$ ), with 5 different doses of ( - )-OSU6162 corresponding to a range of 0.14 $1.25 \mathrm{mg} / \mathrm{kg}$. Because of an experimental error, plasma was not available for one subject. None of the subjects reported any side effects of the drug.

Subject data, administered doses of (-)-OSU6162, plasma concentrations of (-)-OSU6162 and prolactin, and $B P_{N D}$ in the striatum (defined and analyzed using an automated procedure) at baseline and after treatment with ( - )-OSU6162, together with occupancy of D2/D3 receptors are shown in Table 1. Plasma concentrations of $(-)$ OSU6162 ranged from 0.01 to $0.91 \mu \mathrm{M}$ and plasma prolactin levels from 1.89 to $19.29 \mathrm{ng} / \mathrm{ml}$.

Linear relationships were observed between administered dose $(\mathrm{mg} / \mathrm{kg})$ and plasma levels of $(-)$-OSU6162 (Figure 1a) and between plasma concentrations of $(-)$ OSU6161 and prolactin (Figure 1b). It should be noted that subject F had likely not swallowed the ( - )-OSU6162 tablet, as he showed zero plasma levels, a low prolactin level, and no brain D2/D3 receptor occupancy.

For all subjects, $B P_{N D}^{B A S E L I N E}$ values were in close range for the striatum (2.16-2.67). A decreasing $B P_{N D}^{O S U}$ relative to $B P_{N D}^{B A S E L I N E}$, indicating increasing receptor occupancy, was seen with increasing ( - -OSU6162 plasma levels up to $0.2 \mu \mathrm{M}$, at which level D2/D3 receptor occupancy was around 20\%. At higher (-)-OSU6162 plasma concentrations, D2/D3 receptor occupancy leveled off. 
Table I Overview of Subject Data and Findings of the [ ' $\mathrm{C}]$ Raclopride/( - ) OSU6I62 PET Study in Human Volunteers

\begin{tabular}{|c|c|c|c|c|c|c|}
\hline $\begin{array}{l}\text { Subject } \\
\text { code/age }\end{array}$ & $\begin{array}{l}(-) \text {-OSU6 I } 62 \\
\text { Dose (mg/kg) }\end{array}$ & $\begin{array}{l}B P_{N D} \text { striatum }^{a} \\
\text { baseline }\end{array}$ & $\begin{array}{l}B P_{N D} \text { striatum }^{a} \\
\text { pretreatment }\end{array}$ & $\begin{array}{c}\text { Plasma levels } \\
\mu \mathrm{M}\end{array}$ & $\begin{array}{c}\text { Occupancy striatum } \\
\%\end{array}$ & $\begin{array}{c}\text { Prolactin plasma levels } \\
\mathrm{ng} / \mathrm{ml}\end{array}$ \\
\hline $\mathrm{A} / 54$ years & $15 \mathrm{mg}(0.14)$ & 2.41 & 2.29 & 0.09 & 5 & 3.21 \\
\hline $\mathrm{B} / 57$ years & $15 \mathrm{mg}(0.19)$ & 2.28 & 2.02 & NA & 11 & NA \\
\hline C/60 years & $15 \mathrm{mg}(0.16)$ & 2.45 & 2.14 & 0.21 & 13 & 6.18 \\
\hline $\mathrm{D} / 5$ I years ${ }^{\mathrm{b}}$ & $30 \mathrm{mg}(0.4 \mathrm{I})$ & 2.20 & 1.78 & 0.16 & 19 & 1.89 \\
\hline $\mathrm{G} / 57$ years & $45 \mathrm{mg}(0.53)$ & 2.38 & 1.72 & 0.19 & 27 & 5.71 \\
\hline $\mathrm{H} / 59$ years & $60 \mathrm{mg}(0.74)$ & 2.48 & 1.83 & 0.22 & 26 & 5.33 \\
\hline |/5| years & $90 \mathrm{mg}(1.11)$ & 2.22 & 1.72 & 0.48 & 23 & 6.51 \\
\hline J/52 years & $90 \mathrm{mg}(1.25)$ & 2.16 & 1.45 & 0.91 & 33 & 19.29 \\
\hline
\end{tabular}

Abbreviation: NA, not available.

Plasma (-)-OSU6I62 and prolactin levels could not be determined for subject B owing to a blood sampling error.

${ }^{a}$ Data from automated analysis.

${ }^{\text {b }}$ Smokers, refrained from smoking on day of PET scanning.
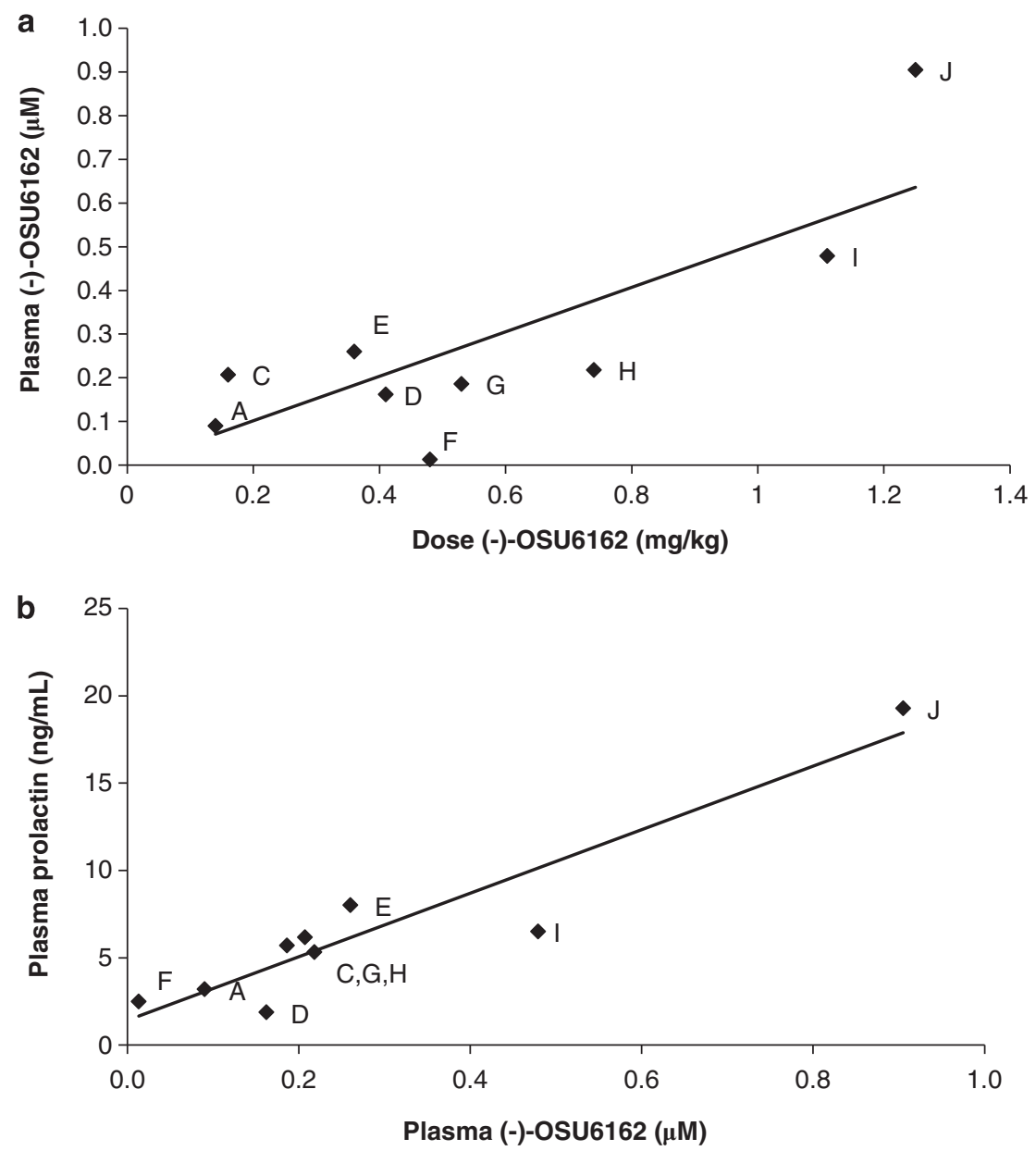

Figure I (a) Plasma ( - -OSU6 I 62 levels $(\mu \mathrm{M})$ as a function of the administered dose of $(-)$-OSU6 I62 (mg/kg). Linear correlation coefficient: $R=0$. 82, $n=9, p<0.01$. (b) Plasma prolactin level as a function of plasma concentration of $(-)$-OSU6I62. Linear correlation coefficient: $R=0.93, n=9$, $p<0.00$ I. Letters indicate individual subjects (see Table I). 


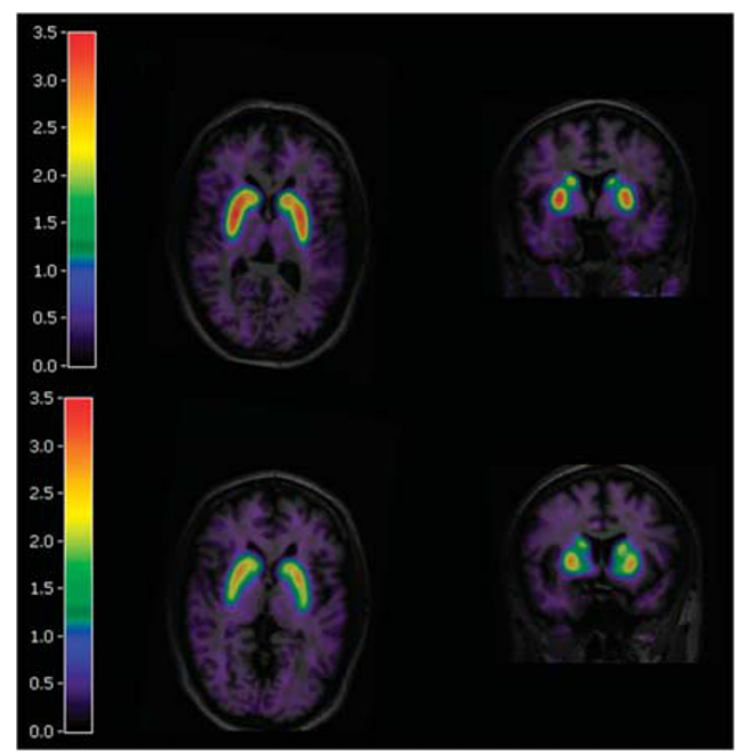

Figure 2 Parametric images of $\left[{ }^{\prime \prime} C\right]$ raclopride $B P_{N D}$ illustrating occupancy of D2/D3 receptors after administration of $90 \mathrm{mg}(-)$ OSU6I62. Top panel: baseline scan, lower panel: scan after treatment with (-)-OSU6I62.

Examples of parametric images of $\left[{ }^{11} \mathrm{C}\right]$ raclopride $B P_{N D}$, illustrating inhibition of $\left[{ }^{11} \mathrm{C}\right]$ raclopride binding after administration of $90 \mathrm{mg}(-)$-OSU6162, are shown in Figure 2. D2/D3 receptor occupancies in the striatum as functions of (-)-OSU6162 plasma levels are shown in Figure 3, together with the curve of best fit to these data using a single-site binding model (Equation 2). The curve fitting yielded an $O c c_{\max }$ of D2/D3 receptor occupancy of approximately $40 \%$ (Table 2 ).

Because of the finding of leveling off and low maximal D2/D3 receptor occupancies by (-)-OSU6162 in the striatum, three striatal subregions, ie, anterior dorsal caudate, anterior dorsal putamen, and ventral striatum, were defined manually and subjected to a similar analysis as the striatum. Plots of D2/D3 receptor occupancy vs (-)-OSU6162 plasma levels for these subregions revealed similar results as for the striatum (graphs not shown). Derived $O c c_{\max }$ and $E C_{50}$-values are presented in Table $2 . O c c_{\max }$ estimates from all regions, mutually compared using a two-tailed $t$-test, were not significantly different ( $p$-value $>0.1)$.

\section{DISCUSSION}

This $\left[{ }^{11} \mathrm{C}\right]$ raclopride PET study aimed to investigate D2/D3 receptor occupancy by the dopamine stabilizer (-)OSU6162 in the striatum of the human brain. A concentration-dependent increase in D2/D3 receptor occupancy, reaching a value of about $20 \%$, was observed for $(-)$ OSU6162 plasma levels of up to $0.2 \mu \mathrm{M}$; above this concentration, occupancy started to level off. Data were fitted well to a single-site binding curve, suggesting a maximum occupancy level of about $40 \%$.

In contrast to this apparent plateauing of striatal D2/D3 receptor occupancy, plasma prolactin levels increased linearly with ( - )-OSU6162 plasma concentrations (Figure 1), which is in agreement with a previous study (Rodriguez et al, 2004). It is likely that this reflects an antagonistic action of (-)-OSU6162 on pituitary dopamine D2 receptors, which in the intact system mediate tonic inhibition of prolactin release. The highest prolactin levels observed in this study, however, were still 2-4 times lower than those found in male patients treated with therapeutic doses of amisulpiride (Bressan et al, 2004), and they were lower than mean prolactin levels in male patients with schizophrenia under antipsychotic treatment (Sugawara et al, 2011).

The present data indicate that striatal D2/D3 receptor occupancy by (-)-OSU6162 reached an asymptotic maximum of about $40 \%$ (Table 2). It was of particular interest to compare occupancy in the ventral striatum, which is associated with limbic structures and strongly innervated by the mesolimbic dopamine system, to dorsal striatal regions, which form the sensorimotor-related part of the striatum (Voorn et al, 2004; Groenewegen, 2007). $\left[{ }^{11} \mathrm{C}\right] \mathrm{ra}-$ clopride $B P_{N D}^{B A S E L I N E}$ values in the ventral striatum were lower than in dorsal striatal areas, confirming previous observations (Mawlawi et al, 2001; Martinez et al, 2003; Alakurtti et al, 2013) and suggesting differences in $\mathrm{D} 2 / \mathrm{D} 3$ receptor densities between striatal regions. The D2/D3 receptor occupancy by ( - )-OSU6162, however, was similar in all the regions investigated. Early PET studies with antipsychotics that are in clinical use for schizophrenia (Farde et al, 1992) indicated that the therapeutic window for an antipsychotic effect in relation to D2/D3 receptor occupancy in the striatum lies between 70 and $80 \%$, above which extrapyramidal side effects occur. This finding has subsequently been verified and fine-tuned to $65-80 \%$ in a large number of PET studies (for a review, see Pani et al, 2007). With antipsychotics displaying partial D2 agonist activity, such as aripiprazole, higher occupancy can be achieved without side effects (Yokoi et al, 2002).

With respect to D2/D3 receptor occupancy, the role of the dissociation rate of drugs from the D2 receptor has been investigated previously. It has been claimed that drugs with relatively low D2 receptor-binding affinity and a fast dissociation rate, such as clozapine and quetiapine, exert antipsychotic activity at lower D2 receptor occupancies, ie, 40-50\% (Seeman and Tallerico, 1999). Among the so-called 'atypical' antipsychotics, quetiapine has the weakest D2 receptor-binding affinity $\left(K_{i}=0.72 \mu \mathrm{M}\right.$; Leysen, 2002), indicating a six times higher potency than (-)-OSU6162 $\left(K_{i}=4.36 \mu \mathrm{M}\right.$; Kara et al, 2010b). It has been reported that ( - )-OSU6162 also displays a fast D2 receptor dissociation rate (Dyhring et al, 2010). PET studies in schizophrenic patients treated with quetiapine showed striatal D2/D3 receptor occupancy of up to $50 \%$. However, $2-3 \mathrm{~h}$ after a single dose, a transiently high occupancy of $58-64 \%$ was observed (Kapur et al, 2000; Gefvert et al, 2001). Recently, a novel compound with fast off rate from the D2 receptor, JNJ-37822681, showed a regular saturation curve of D2/D3 receptor occupancy of up to $70 \%$ (Te Beek et al, 2012). JNJ37822681 showed very good uptake in the brain and a moderate affinity for the D2 receptor $\left(K_{i}=0.158 \mu \mathrm{M}\right)$, comparable with clozapine $\left(K_{i}=0.137 \mu \mathrm{M}\right.$; Langlois et al, 2012). Hence, neither low (in vitro) D2 receptor affinity nor fast dissociation rate seems to be a general cause for low D2 receptor occupancy of a drug.

Comparisons between the present findings in humans and animal data obtained previously are difficult due 


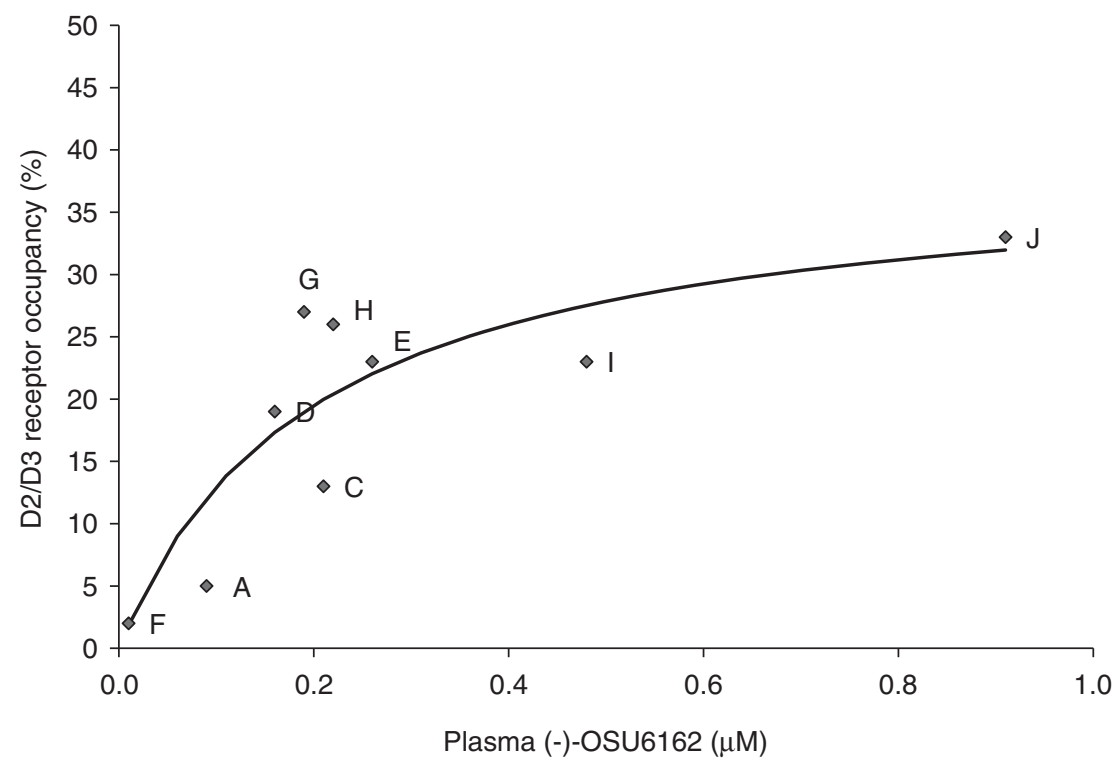

Figure 3 D2/D3 receptor occupancy in the striatum as a function of plasma concentration of ( - )-OSU6I62. Letters indicate individual subjects (see Table I).

Table 2 Estimates of Maximal D2/D3 Receptor Occupancy (Occ max) and EC $50^{-V}$ Values of ( - )-OSU6I62 in Human Striatal Regions

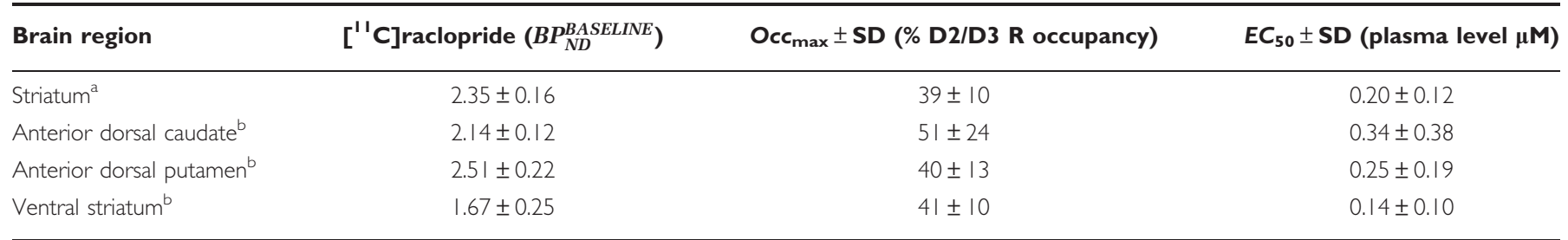

All values are mean $\pm \mathrm{SD}, n=9$.

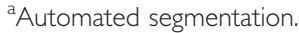

bManually defined regions.

to differences in dosage and route of administration. A previous PET study, investigating D2/D3 receptor occupancy by (-)-OSU6162 in rhesus monkeys, revealed an occupancy of up to $75 \%$ (Ekesbo et al, 1999). In that study, ( - )-OSU6162 was administered to anesthetized animals by continuous IV infusion of up to $3 \mathrm{mg} / \mathrm{kg} / \mathrm{h}$. In a rat study (Natesan et al, 2006), increasing subcutaneous doses of (-)-OSU6162 of up to $120 \mathrm{mg} / \mathrm{kg}$ resulted in a D2/D3 receptor occupancy plateau of about $90 \%$. Therefore, it appears that D2/D3 receptor occupancy in humans, in a clinically relevant dosage range, as far as can be judged by the data available, is lower than in non-human vertebrates, where much higher dose ranges were applied.

The degree of D2/D3 receptor occupancy in human striatal brain regions, as compared with that of the antipsychotic drugs mentioned above, illustrates a unique feature of ( - -OSU6162 that may help to elucidate its dopamine-stabilizing properties. Various explanations can be proposed for the partial occupancy of D2/D3 receptors in vivo. D2 receptors have been reported to function as asymmetrical dimers (Han et al, 2009; Kara et al, 2010a). It is possible that either ( - -OSU6162 has a preference for certain dimers or that raclopride and $(-)$-OSU6162 bind to allosteric sites, which are only partially mutually exclusive.
These hypotheses, however, are hard to investigate and prove experimentally.

A possible explanation for the different results in human and non-human species could be that we are dealing with a biphasic binding curve. This could theoretically arise from a reduction in specific receptor labeling by $\left[{ }^{11} \mathrm{C}\right]$ raclopride caused by both unlabeled (-)-OSU6162 and increased extracellular dopamine. Treatment with (-)-OSU6162, because of the blockade of D2/D3 autoreceptors, will stimulate the activity of dopaminergic neurones and thus cause an increase in dopamine release. Because of the preferential blockade of dopaminergic autoreceptors (Carlsson et al, 2004), the contribution of endogenous dopamine following low doses of the drug would be high, and this should lead to a relatively steep initial rise of the binding curve. However, when the dose-dependent binding to the autoreceptors is reaching saturation the rise will slow down. With further increasing dosage, the relative contribution of ( - )-OSU6162 to the displacement of $\left[{ }^{11} \mathrm{C}\right]$ raclopride will increase, and the binding curve would then again assume a steeper course. To demonstrate this further increase in humans would, however, require doses higher than those used in the present study, and such high doses may not be well tolerated. 
According to another hypothesis, which would not be incompatible with the previous one, (-)-OSU6162 will preferentially bind to extrasynaptic D2/D3 receptors (Carlsson and Carlsson, 2006). The D2 autoreceptors belong to the extrasynaptic subpopulation of dopaminergic receptors, and it is reasonable to assume that the blocking action of (-)-OSU6162 extends to all extrasynaptic D2/D3 receptors. Hence, it might be concluded from the present data that the extrasynaptic subpopulation of the D2/D3 receptor represents $<40 \%$ of the total D2/D3 receptor population in human striatal regions. The presumed selectivity of (-)-OSU6162 for extrasynaptic D2/D3 receptors seems to provide a plausible explanation for some unique aspects of its pharmacological profile. Behavioral stimulation of individuals (animals or humans) displaying a low psychomotor activity could be due to a blocking action on autoreceptors, which at low doses may prevail over a blocking action on heteroreceptors (Rung et al, 2008, Carlsson et al, 2011, Johansson et al, 2012). With increasing dose of (-)-OSU6162, however, its action on extrasynaptic heteroreceptors will increase and thus counterbalance its effect on autoreceptors. Ultimately, the effect on the heteroreceptors will prevail, especially under conditions of high behavioral baseline levels, thus causing reduced psychomotor activity. Lack of binding to synaptic heteroreceptors could explain both the virtually complete absence of extrapyramidal side effects and the lack of a number of non-motor side effects. The buffering effect of (-)-OSU6162 on brain dopaminergic transmission, ie, its ability to mitigate both deficient and excessive dopamine activity, may at least in part explain why this compound has shown promise in conditions as disparate as Huntington's disease, schizophrenia, Parkinson's disease, and mental fatigue following brain trauma and stroke (Tedroff et al, 1999; Johansson et al, 2012; Kloberg et al, 2014; Carlsson A, unpublished observations).

The interpretation of the binding data given above, although plausible, should still be considered tentative, given the limited number of subjects. For example, although data fit in well with a single-site binding curve, the conclusion that this curve is leveling off with a maximum around $40 \%$ may be questioned, especially in view of the animal data showing a much higher binding capacity of ( - )-OSU6162 to dopamine D2/D3 receptors. A limitation of the study is the small number of data points between plasma levels of $0.4-0.9 \mu \mathrm{M}$, which could have caused an apparent leveling off. In spite of our study design with dosages well spread out between subjects, the measured plasma levels showed some clustering leading to limited data points between $0.4-0.9 \mu \mathrm{M}$. This was probably due to some differences in pharmacokinetics between subjects along with the fact that plasma levels could not be obtained for three subjects (two subjects were excluded from the study, and for one subject, plasma levels could not be measured due to an experimental error). Furthermore, the lack of data points beyond a dose of $90 \mathrm{mg}$ could also cause the apparent leveling off. The perceived species difference could therefore also arise from the fact that the dosage of the compound to humans has to be limited for tolerability reasons. Future studies are needed to clarify these issues.

\section{FUNDING AND DISCLOSURE}

This work was financially supported by The Netherlands Brain Foundation, Project no. 2010(1)-13. The authors declare no conflict of interest.

\section{REFERENCES}

Alakurtti K, Johansson JJ, Tuokkola T, Nägren K, Rinne JO (2013). Rostrocaudal gradients of dopamine $\mathrm{D}_{2 / 3}$ receptor binding in striatal subregions measured with $\left[{ }^{11} \mathrm{C}\right]$ raclopride and high-resolution positron emission tomography. Neuroimage 82: 252-259.

Bressan RA, Erlandsson K, Spencer EP, Ell PJ, Pilowsky LS (2004). Prolactinemia is uncoupled from central D2/D3 dopamine receptor occupancy in amisulpride treated patients. Psychopharmacology (Berl) 175: 367-373.

Brix G, Zaers J, Adam LE, Bellemann ME, Ostertag H, Trojan H et al (1997). Performance evaluation of a whole-body PET scanner using the NEMA protocol. National Electrical Manufacturers Association. J Nucl Med 38: 1614-1623.

Burstein ES, Carlsson ML, Owens M, Ma JN, Schiffer HH, Carlsson A et al (2011). II. In vitro evidence that ( -$)$-OSU6162 and (+)OSU6162 produce their behavioral effects through 5-HT2A serotonin and D2 dopamine receptors. J Neural Transm 118: 1523-1533.

Carlsson A, Carlsson ML (2006). A dopaminergic deficit hypothesis of schizophrenia: the path to discovery. Dialogues Clin Neurosci 8: 137-142.

Carlsson ML, Burstein ES, Kloberg A, Hansson S, Schedwin A, Nilsson $M$ et al (2011). I. In vivo evidence for partial agonist effects of ( - )-OSU6162 and (+)-OSU6162 on 5-HT2A serotonin receptors. J Neural Transm 118: 1511-1522.

Carlsson ML, Carlsson A, Nilsson M (2004). Schizophrenia: from dopamine to glutamate and back. Curr Med Chem 11: 267-277.

Dyhring T, Nielsen EO, Sonesson C, Pettersson F, Karlsson J, Svensson $\mathrm{P}$ et al (2010). The dopaminergic stabilizers pridopidine (ACR16) and (-)-OSU6162 display dopamine $D(2)$ receptor antagonism and fast receptor dissociation properties. Eur J Pharmacol 628: 19-26.

Ehrin E, Gawell L, Hogberg T, de Paulis T, Strom P (1987). Synthesis of [methoxy-3H]- and [methoxy-11C]-labelled raclopride. Specific dopamine-D2 receptor ligands. J Labell Compounds Radiopharm 24: 931-940.

Ekesbo A, Torstenson R, Hartvig P, Carlsson A, Sonesson C, Waters $\mathrm{N}$ et al (1999). Effects of the substituted (S)-3-phenylpiperidine (-)-OSU6162 on PET measurements of [11C] SCH23390 and [11C]raclopride binding in primate brains. Neuropharmacology 38: 331-338.

Farde L, Nordstrom AL, Wiesel FA, Pauli S, Halldin C, Sedvall G (1992). Positron emission tomographic analysis of central D1 and D2 dopamine receptor occupancy in patients treated with classical neuroleptics and clozapine. Relation to extrapyramidal side effects. Arch Gen Psychiatry 49: 538-544.

Gefvert O, Lundberg T, Wieselgren IM, Bergstrom M, Langstrom $\mathrm{B}$, Wiesel $\mathrm{F}$ et al (2001). $\mathrm{D}(2)$ and $5 \mathrm{HT}(2 \mathrm{~A})$ receptor occupancy of different doses of quetiapine in schizophrenia: a PET study. Eur Neuropsychopharmacol 11: 105-110.

Groenewegen HJ (2007). The ventral striatum as an interface between the limbic and motor systems. CNS Spectr 12: 887-892.

Han Y, Moreira IS, Urizar E, Weinstein H, Javitch JA (2009). Allosteric communication between protomers of dopamine class A GPCR dimers modulates activation. Nat Chem Biol 5: 688-695.

Innis RB, Cunningham VJ, Delforge J, Fujita M, Gjedde A, Gunn RN et al (2007). Consensus nomenclature for in vivo imaging of reversibly binding radioligands. J Cereb Blood Flow Metab 27: 1533-1539. 
Johansson B, Carlsson A, Carlsson ML, Karlsson M, Nilsson MKL, Nordquist-Brandt E et al (2012). Placebo-controlled cross-over study of the monoaminergic stabiliser (-)-OSU6162 in mental fatigue following stroke or traumatic brain injury. Acta Neuropsychiatr 24: 266-274.

Kapur S, Zipursky R, Jones C, Shammi CS, Remington G, Seeman P (2000). A positron emission tomography study of quetiapine in schizophrenia: a preliminary finding of an antipsychotic effect with only transiently high dopamine D2 receptor occupancy. Arch Gen Psychiatry 57: 553-559.

Kara E, Lin H, Strange PG (2010a). Co-operativity in agonist binding at the D2 dopamine receptor: evidence from agonist dissociation kinetics. J Neurochem 112: 1442-1453.

Kara E, Lin H, Svensson K, Johansson AM, Strange PG (2010b). Analysis of the actions of the novel dopamine receptor-directed compounds (S)-OSU6162 and ACR16 at the D2 dopamine receptor. Br J Pharmacol 161: 1343-1350.

Kloberg A, Constantinescu R, Nilsson MKL, Carlsson ML, Carlsson A, Wahlström J et al (2014). Tolerability and efficacy of the monoaminergic stabilizer (-)-OSU6162 (PNU-96391A) in Huntington's disease: a double-blind cross-over study. Acta Neuropsychiatrica (doi:10.1017/neu.2014.16).

Lahti RA, Tamminga CA, Carlsson A (2007). Stimulating and inhibitory effects of the dopamine 'stabilizer' (-)-OSU6162 on dopamine D2 receptor function in vitro. J Neural Transm 114: 1143-1146.

Langlois X, Megens A, Lavreysen H, Atack J, Cik M, te RP et al (2012). Pharmacology of JNJ-37822681, a specific and fastdissociating D2 antagonist for the treatment of schizophrenia. J Pharmacol Exp Ther 342: 91-105.

Leysen JE (2002). Atypical antipsychotics. In: Di Chiara G eds. Handbook of Experimental Pharmacology Vol 154/II (Springer Verlag: Berlin, Heidelberg, Germany, pp 473-490.

Maes F, Collignon A, Vandermeulen D, Marchal G, Suetens P (1997). Multimodality image registration by maximization of mutual information. IEEE Trans Med Imaging 16: 187-198.

Martinez D, Slifstein M, Broft A, Mawlawi O, Hwang DR, Huang Y et al (2003). Imaging human mesolimbic dopamine transmission with positron emission tomography. Part II: amphetamine-induced dopamine release in the functional subdivisions of the striatum. J Cereb Blood Flow Metab. 23: 285-300.

Mawlawi O, Martinez D, Slifstein M, Broft A, Chatterjee R, Hwang DR et al (2001). Imaging human mesolimbic dopamine transmission with positron emission tomography: I. Accuracy and precision of $\mathrm{D}(2)$ receptor parameter measurements in ventral striatum. J Cereb Blood Flow Metab 21: 1034-1057.

Natesan S, Svensson KA, Reckless GE, Nobrega JN, Barlow KB, Johansson AM et al (2006). The dopamine stabilizers (S)-(-)(3-methanesulfonyl-phenyl)-1-propyl-piperidine [(-)-OSU6162] and 4-(3-methanesulfonylphenyl)-1-propyl-piperidine (ACR16) show high in vivo D2 receptor occupancy, antipsychotic-like efficacy, and low potential for motor side effects in the rat. J Pharmacol Exp Ther 318: 810-818.

Pani L, Pira L, Marchese G (2007). Antipsychotic efficacy: relationship to optimal D2-receptor occupancy. Eur Psychiatry 22: $267-275$.

Rodriguez CA, Azie NE, Adams G, Donaldson K, Francom SF, Staton BA et al (2004). Single oral dose safety, tolerability, and pharmacokinetics of PNU-96391 in healthy volunteers. J Clin Pharmacol 44: 276-283.

Rung JP, Rung E, Helgeson L, Johansson AM, Svensson K, Carlsson A et al (2008). Effects of (-)-OSU6162 and ACR16 on motor activity in rats, indicating a unique mechanism of dopaminergic stabilization. J Neural Transm 115: 899-908.

Rung JP, Rung E, Johansson AM, Svensson K, Carlsson A, Carlsson ML (2011). Effects of the dopamine stabilizers (S)(-)-OSU6162 and ACR16 on prolactin secretion in drug-naive and monoamine-depleted rats. Naunyn Schmiedebergs Arch Pharmacol 384: 39-45.

Sahlholm K, Arhem P, Fuxe K, Marcellino D (2013). The dopamine stabilizers ACR16 and (-)-OSU6162 display nanomolar affinities at the sigma-1 receptor. Mol Psychiatry 18: 12-14.

Seeman P, Tallerico T (1999). Rapid release of antipsychotic drugs from dopamine D2 receptors: an explanation for low receptor occupancy and early clinical relapse upon withdrawal of clozapine or quetiapine. Am J Psychiatry 156: 876-884.

Sonesson C, Lin CH, Hansson L, Waters N, Svensson K, Carlsson A et al (1994). Substituted (S)-phenylpiperidines and rigid congeners as preferential dopamine autoreceptor antagonists: synthesis and structure-activity relationships. J Med Chem 37: $2735-2753$.

Sugawara N, Yasui-Furukori N, Fujii A, Saito M, Sato Y, Nakagami $\mathrm{T}$ et al (2011). No association between bone mass and prolactin levels among patients with schizophrenia. Hum Psychopharmacol 26: 596-601.

Svarer C, Madsen K, Hasselbalch SG, Pinborg LH, Haugbol S, Frokjaer VG et al (2005). MR-based automatic delineation of volumes of interest in human brain PET images using probability maps. Neuroimage 24: 969-979.

Svensson KA, Falcone JF, Johansson AM, Perry KW, Fell MA (2009): The actions of the dopamine stabilizer ACR16, but not ( - )-OSU6162, in behavioral and neurochemical assays are not dependent on the presence of functional D2 receptors. Society for Neuroscience (Washington, DC), Annual Meeting; 9-13 Nov 2009; San Diego, CA, USA.

Te Beek ET, de BP, Moerland M, Schmidt ME, Hoetjes NJ, Windhorst $\mathrm{AD}$ et al (2012). In vivo quantification of striatal dopamine D2 receptor occupancy by JNJ-37822681 using [11C]raclopride and positron emission tomography. J Psychopharmacol 26: 1128-1135.

Tedroff J, Ekesbo A, Sonesson C, Waters N, Carlsson A (1999). Long-lasting improvement following (-)-OSU6162 in a patient with Huntington's disease. Neurology 53: 1605-1606.

Voorn P, Vanderschuren LJMJ, Groenewegen HJ, Robbins TW, Pennartz CMA (2004). Putting a spin on the dorsal-ventral divide of the striatum. Trends Neurosci 27: 468-474.

Wienkers LC, Wynalda MA (2002). Multiple cytochrome P450 enzymes responsible for the oxidative metabolism of the substituted (S)-3-phenylpiperidine, (S,S)-3-[3-(methylsulfonyl)phenyl]-1-propylpiperidine hydrochloride, in human liver microsomes. Drug Metab Dispos. 30: 1372-1377.

$\mathrm{Wu}$ Y, Carson RE (2002). Noise reduction in the simplified reference tissue model for neuroreceptor functional imaging. J Cereb Blood Flow Metab 22: 1440-1452.

Yamazaki S, Toth LN, Kimoto E, Bower J, Skaptason J, Romero D et al (2009). Application of stable isotope methodology in the evaluation of the pharmacokinetics of (S,S)-3-[3-(methylsulfonyl)phenyl]-1-propylpiperidine hydrochloride in rats. Drug Metab Dispos 37: 937-945.

Yokoi F, Gründer G, Biziere K, Stephane M, Dogan AS, Dannals RF et al (2002). Dopamine $\mathrm{D}_{2}$ and $\mathrm{D}_{3}$ receptor occupancy in normal humans treated with the antipsychotic drug aripiprazole (OPC 14597): a study using positron emission tomography and $\left[{ }^{11} \mathrm{C}\right]$ raclopride. Neuropsychopharmacology 27: 248-259. 